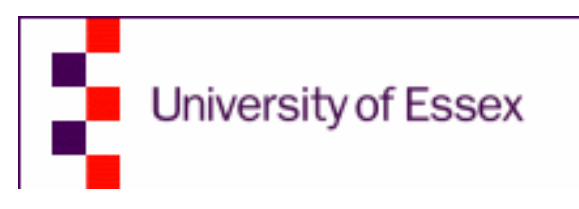

SCHOOL OF ACCOUNTING, FINANCE AND MANAGEMENT

Moving Management:

Theorizing Struggles against the Hegemony of Management

André Spicer

Warwick Business School

Steffen Böhm

University of Essex

Working Paper No. WP 07/06

November, 2007 


\title{
Moving Management: Theorizing Struggles against the Hegemony of Management ${ }^{*}$
}

\author{
André Spicer \\ Steffen Böhm \\ Industrial Relations and \\ Department of Accounting, \\ Organizational Behaviour, \\ Finance and Management, \\ Warwick Business School, \\ University of Essex, \\ Wivenhoe Park, \\ University of Warwick, \\ Coventry CV4 7AL, \\ United Kingdom. \\ Colchester C04 3SQ, \\ United Kingdom. \\ andre.spicer@wbs.ac.uk \\ steffen@essex.ac.uk
}

April 2007

Resubmitted to: Organization Studies (OS 2005/488c)

André Spicer is an Associate Professor of Organization Studies at the University of Warwick. He holds a PhD from the University of Melbourne, Australia. His work focuses on developing a political theory of organization. He has conducted research on entrepreneurship, globalization in public broadcasting, labour disputes in ports, organizational resistance and open source technology. He is co-author of Contesting the Corporation (Cambridge University Press) and Unmasking the Entrepreneur (Forthcoming, Edward Elgar).

Steffen Böhm is Lecturer in Management at the University of Essex. He holds a PhD from the University of Warwick, UK. His research focuses on the politics of organizing. He is co-founder and member of the editorial collective of the open-access journal ephemera: theory \& politics in organization (www.ephemeraweb.org), and co-founder and co-editor of the new open publishing press mayflybooks (www.mayflybooks.org). He has authored Repositioning Organization Theory (Palgrave) and co-edited Against Automobility (Blackwell).

\footnotetext{
* This paper was originally presented at the Collective for Alternative Organization Studies workshop at the University of Leicester in May 2004. We are grateful to the participants for their feedback. We would particularly like to thank Peter Fleming, Campbell Jones, Chris Land, Mel Strauss and four anonymous Organization Studies reviewers for their advice and suggestions.
} 


\title{
Moving Management: \\ Theorizing Struggles against the Hegemony of Management
}

\begin{abstract}
How do groups resist the apparently all encompassing discourse of management? Rejecting current theories of resistance as 're-appropriation' or 'micro-politics', we argue that resistance may be thought about as hegemonic struggle which are undertaken by social movements. We identify four major resistance movements that engage with management: unions, organizational misbehaviour, civic movements, and civic movement organizations. We argue that these forms of resistance differ in terms of location (civil society or workplace) and strategy (political or infra-political). We chart out the possible interconnections between these different modes of resistance and detail how these interconnections are established. By doing this, the paper provides a framework for understanding the many forms of resistance movements that seek to disrupt the hegemonic discourse of management.
\end{abstract}

Keywords: Resistance. Social Movements. Civil Society. Discourse. Hegemony. Management. 


\section{Introduction}

One of the defining features of organizations in the latter part of the twentieth century has been the increasing influence of management (Parker 2002; Grey 2004). We have witnessed the spread of management from large corporations into the professions (Deem 1998), the public sector (Pollitt 1993), the non-profit sector (Eikenberry and Kluver 2004), and everyday life (Hancock and Tyler forthcoming). Organization theorists have conceptualized the spread of management in a variety of ways, such as a change in the governance mechanisms in an organization (Crouch 2005), a shift in the locus of control in organizations (Fligstein 1990), a move in patterns of professional dominance (Shenhav 1999), or a transformation of the logic which characterizes the firm (Thornton 2004). One dimension which has received particular attention is how the spread of management has involved the spread of the discourse of management. A discourse is a structured set of texts and practices which is produced, distributed, and consumed by actors in a way which constructs objects and subjects in the social world (Fairclough 1995). The discourse of management is a set of languages and practices proliferated through forms of disciplined knowledge that produce a world which is amenable to control by managers and technologies of management (Parker 2002: 1-16). The discourse of management can be found in a wide variety of forms, including individual narratives, self-help books, training programmes, corporate strategy and government 'modernization' policies (Grant et al. 2004). Indeed, some even claim that discourses of management have become so widespread that they are almost inescapable (Thrift 2002; Chiapello and Fairclough 2002).

Despite the apparently unconstrained reach of management discourses, a growing literature reminds us that it may not be so all-consuming and over-powering. This work has demonstrated that discourses of management are embattled by a range of rebels, including disgruntled public sector employees (Thomas and Davies 2005), unionists (Hyman 1973), shareholder activists (Davis and Thompson 1994), environmental pressure groups (Lounsbury 2001), and social movements (Davis et al. 2005). What is so striking about these struggles is that they take on so many different forms. In this paper we want to explore these many forms of resistance by asking, how we understand these multiple forms of resistance against discourses of management. 
In order to understand the multiple forms of resistance, we shall draw on a deep and rich tradition of literature on the topic. We will argue that both labour process theory (LPT) (e.g. Braverman 1974; Ackroyd and Thompson 1999) and Foucauldian studies of the workplace (e.g. Knights and MacCabe 2000) expose how discourses of management are resisted in different situations at work (e.g. Ackroyd and Thompson 1999; Knights and Willmott 1989). What these studies do not provide us is an account of how discourses of management are collectively called into question outside the workplace. Building on the political theories of Ernesto Laclau and Chantal Mouffe (1985; 2001), we argue that managerial discourses are the target of counter-hegemonic, collective struggles undertaken by social movements. We posit that these movements take place in civil society as well as the workplace. This means that instead of privileging one kind of resistance movement, it is necessary to consider how discourses of management are resisted by multiple movements in both the workplace and civil society. To do this we develop a multi-modal theory of resistance to the discourses of management. This allows us, first, to identify the various kinds of movements which seek to resist the discourses of management, second, analyze the characteristics of these movements, and, third, examine the conditions of when they might arise. Further, we argue that many collective struggles against management involve a number of different social movements at once. By investigating the linkages between different kinds of movements, we aim to show how management is resisted through shifting alliances of anti-managerial discourses which are articulated by a variety of different counterhegemonic movements.

\section{Resistance in Organization and Management Studies}

\section{Resistance as Re-appropriation}

Labour process theory (LPT) provides one of the most well developed accounts of how people resist management (Burawoy 1979; Jermier, Knights \& Nord 1994; Knights and Willmott 1990). Following Marx (1976) and Braverman (1974), labour process theorists reject the functionalist notion that resistance is the result of a rational individual agent trying to achieve their own personal goals. Rather, resistance is understood to be the inevitable result of the objective exploitation of labour by capital. This objective exploitative relationship gives rise to an inherent antagonism between labour and capital which frequently produces resistance. The prime location for resistance is the capitalist 
workplace precisely because this is the place where capital and labour are structurally locked into a power struggle over economic resources (e.g. Ackroyd and Thompson 1999; Thompson 1990; Thompson and Ackroyd 1995; Thompson and Smith 2001). The aim of the resistance against management in the workplace is the re-appropriation of critical 'goods' which the labour process systematically takes from the worker, such as time, work, products, and their sense of self (Ackroyd and Thompson 1999).

Perhaps the most notable forms of re-appropriation identified by labour process theory are luddite protests (Thompson 1967), guild-based syndicalism (Cole 1917), and, most importantly, the trade union movement. A wide repertoire of strategies of organized workplace resistance have developed out of the union movement: for example, workplace strikes, which range from bitter and long-running industrial disputes through to largely symbolic downing of tools (Hyman 1973), negotiating and bargaining with representatives of capital over the terms and conditions of employment, intervening in national politics, and 'consciousness raising'. Alongside this official repertoire of unionised resistance is a whole battery of unofficial, but highly organized strategies of workers’ struggles. These include wildcat strikes (Gouldner 1954), 'go-slows’ (Green 1992), and 'working-to-rule'. Despite the relative decline in unions' power since the 1980s (Disney et al. 1995; Wallerstein and Western 2000), unions continue to play an important role in the workplace. Moreover, new forms of union organization have recently appeared, such as trans-national unionism (Munck 2000), ‘community’ or 'social movement' unionism (Clawson and Clawson 1999), and on-line unionism (Carter et al. 2003). These innovations remind us that union politics is far from outdated. On the contrary, union organization continuously evolves and adapts and therefore continues to be an important way of resisting the hegemony of management.

Labour process theory has also frequently observed many less public modes of reappropriation in the workplace. These include informal practices such as 'banana time' (Roy 1958), co-ordinated and systematic rule bending (Bensman and Gerver 1963), and 'making out' practices (Burawoy 1979). In their comprehensive study of the topic, Ackroyd and Thompson (1999) argue that informal resistance activities in the workplace - which they name 'organizational misbehaviour' - include a variety of strategies of re-appropriation: attempts to re-appropriate time through activities like time-wasting (Ditton 1972); re-appropriate work through activities like sabotage 
(Brown 1977); re-appropriate the product through activities like theft (Mars 1982); and re-appropriate workers' identities through activities like the use of humour which is directed against management (Taylor and Bain 2002).

Labour process theory provides a rich body of empirical studies of how workers resist the edicts of management through both formal and informal means. Despite this obvious strength, labour process theory has a number of shortcomings. First, it has been called into question for not providing an adequate account of how employees subjectively engage and understand their workplace contexts (Knights and Willmott 1989). This means that traditional labour process theory makes it difficult for us to take account of the everyday ways employees make sense of and negotiate their workplaces. Second, traditional labour process theory has been criticized for providing an overly determinist account of resistance in the workplace. This is because it has tended to focus on the structural causes of resistance, rather than consider the potential spaces of agency and minor degrees of freedom which are enjoyed by employees (Knights and MacCabe 2000).

\section{Resistance as Micro-politics}

In order to address these perceived shortcomings in labour process accounts, some studying workplace resistance have taken inspiration from the work of Michel Foucault (e.g. Knights and MacCabe 2000, 2003; Ball and Wilson 2000; Doolin 2002; Thomas and Davies 2005). For Foucault (e.g. 1970, 1991), social reality is produced through a range of disciplinary, everyday micro-practices that amount to powerful institutional discourses constructing modern subjectivities such as the worker, the prisoners and the patient. These subjectivities are produced through complex processes of power, knowledge and resistance. With Foucault, the emphasis shifts from structural, classbased analysis of power and resistance, which are the focus of many labour process analysts, such as Braverman (1974), to discursive dynamics of the construction of subjectivities and the epistemological and ethical complexities this entails. Hence, the Foucauldian response to traditional labour process theory is one that emphasizes the expansion of our understanding of the organization of power and resistance beyond the narrow conceptions of economic class antagonisms in the workplace. According to Foucauldian approaches, resistance involves informal 'micro-politics' which can be conceptualized as the "constant process of adaptation, subversion and reinscription of 
dominant discourses" which takes place as "individuals confront, and reflect on, their own identity performance, recognizing contradictions and tensions and, in so doing, pervert and subtly shift meanings and understandings” (Thomas and Davies 2005: 687).

A growing group of researchers have enthusiastically explored the micro-political dynamics through which employees contest managerially imposed subject positions. This has typically involved in-depth explorations of the complexities of identity politics in and around the workplace (Thomas et al. 2004). This includes considerations of how employees resist the colonization of their subjectivity through out-right rejection of managerial identity, feigned acceptance or pragmatic negotiation (Knights and MacCabe 2000, 2003; Ball and Wilson 2000; Doolin 2002; Thomas and Davies 2005), the negotiations of masculine identities (Collinson 1992, 2003), and the expression of dissatisfaction through cynicism and ambivalence (Whittle 2005).

Accounts of workplace resistance inspired by Michel Foucault certainly take us beyond the restricted concerns of the economic relationships and help us to explore the micropolitics of negotiating subjectivities and identities in organizations. However, they have also been critiqued for a number of reasons. Some have argued that Foucauldian accounts of the workplace often introduce a kind of discursive determinism (Newton 1998, 1999; Reed 1997). That is, they assume that an individual's sense of agency is completely circumscribed and determined by the discourse they inhabit. This means that it is "hard to get a sense of how active agential selves 'make a difference' through 'playing' with discursive practices” (Newton 1998: 425-6). Even when Foucauldian researchers have endeavoured to register how 'active agential selves' play with a discourse, they have often focused on individual or at best small group struggles, at the expense of broader collective struggles (Ganesh et al. 2005). The result is that Foucauldian approaches are able to tell us a lot about specific micro-political workplace struggles, but they have often side-stepped the collective struggles against the discourses of management in the wider realms of society (Contu 2002; Böhm 2006).

\section{Resistance as Hegemonic Struggle}

In order to register how agents, particularly collective agents, engage in struggles with discourses of management, we shall turn to the analytical framework provided by Laclau and Mouffe (1985). Building on earlier work on hegemony (e.g. Gramsci 1971), 
they argue that the locus of resistance is not micro-politics in everyday organizational life; instead, resistance involves a collective process of hegemonic struggle. They define hegemony as a "unity existing in a concrete social formation" (Laclau and Mouffe 1985: 7). Hegemony is achieved when “a particular social force assumes the representation of a totality that is radically incommensurable with it” (Laclau and Mouffe 2001: x, emphasis in original). This means that power and resistance do not only exist in form of particular, micro-political events; instead, they are articulated as part of wider hegemonic discourses.

The first crucial point here is that hegemony involves articulation. That is, hegemony is established when a single discourse stands in for the whole. For instance, managerial hegemony is achieved when the exhortations of management are thought to represent the concerns of all different actors in an organization. This can only come to pass when 'chains of equivalence' are formed between a variety of different, sometimes competing, discourses (Laclau and Mouffe 1985: 130). The result is that a hegemonic discourse is created that comes to sit at the discursive centre of a complex web of social relations. The second crucial point is that hegemony involves struggle. If we return to Laclau and Mouffe's definition, we notice that a hegemonic discourse always remains 'radically incommensurable' with the whole. This is because it can never perfectly map onto and describe the social as totality. For instance, the dreams and schemes of management will never adequately represent all the interests in a contemporary organization. The result is that any dominant discourse will remain 'necessarily incomplete' (Laclau and Mouffe 1985: 111). This means any form of hegemony is deemed to be momentary and therefore contingent (Laclau and Mouffe 1985: 65). This contingency and incompleteness of any discursive hegemony means that resistance always lurks within any hegemonic regime. The final point is that hegemonic struggle is undertaken by social movements. That is, social movements are the major actors who seek to forge articulations or linkages between what are apparently distinct struggles. For instance, the union movement of the $18^{\text {th }}$ and $19^{\text {th }}$ centuries was able to articulate the concerns of different occupational groups such as carpenters and miners so that they all began to see themselves as being part of a single group called 'the working class' (Thompson 1967). 
Some have found Laclau and Mouffe's concept of hegemony particularly useful for understanding the particular dominance of discourses of management. According to Parker, today's discourse of management can be understood as "generalized technology of control” and indeed as "hegemonic model of organization” (2002: 184). ${ }^{1}$ That is, the single discourse of management has been articulated or linked with a remarkable range of other discourses ranging from medicine to public administration to development. The result is that this particular discourse has assumed a certain hegemonic totality. It has become a single language that purports to explain absolutely everything. Despite the apparent totality of the management discourse, it continues to remain open to hegemonic struggle. That is, the apparent unity of the discourse of management can only be a partial one. This is because the hegemony of management is always fragile and open to contestation and resistance. This resistance occurs because social movement actors continuously seek to “articulating and developing 'chains of equivalence' amongst diverse struggles” (Willmott 2005: 772), in order to challenge the apparent discursive unity of the management discourse.

We very much agree with Willmott's view here that Laclau and Mouffe (1985, 2001) open up new ways of understanding resistance as hegemonic struggle. However, what is missing in Willmott's (2005) analysis is a framework for understanding the agency involved in this hegemonic struggle. He acknowledges that hegemonic struggles are taken forward by social movements, but he does not address exactly how these social movements operate, and the wide variety of forms that they take in all spheres of society. In order to provide a conceptualization of exactly how these social movements might attempt to engage in hegemonic struggles against management, we shall turn to social movement theory. We will argue that this provides a detailed understanding of the various processes involved in actually organizing resistance. Perhaps more importantly, social movement theory alerts organization studies to the fact that resistance and struggles against the discourses of management can take on many different manifestations in different sectors of social life.

\footnotetext{
1 In organization and management studies the concept of hegemony has generally been rather underexposed. Yet, in recent years writers have increasingly utilized the concept in order to critique managerial discourses in the fields of organizational learning (Contu and Willmott, 2003), strategic management (Levy and Egan, 2003), global production networks (Levy, 2007), training programmes (Brown and Coupland, 2005), management education (Elliott, 2003), organizational culture (Ogbor, 2001), entrepreneurship (Jones and Spicer, 2005), organization theory (Böhm, 2006), industrial relations (Haworth and Hughes, 2003) and institutional entrepreneurship (Levy and Scully, 2007).
} 


\section{Social Movements}

Laclau and Mouffe $(1985,2001)$ suggest that social movements are the central agents of resistance. What they do not do is go into any further detail about exactly how social movements organize their hegemonic struggles. In the spirit of recent attempts to provide a more details account of the agency involved in crafting hegemonic links (Levy and Scully 2007), we shall turn to social movement theory (see, for example, Crossley 2002; Davis et al. 2005; Della Porta and Diani 1999; Kelly 1998; McAdam et al. 1996; Melucci 1989, 1996; Touraine 1981; Zald and McCarthy 1987; Zald and Berger 1978; and Zald 2005). A social movement might be broadly defined as "collective challenges by people with common purposes and solidarity in sustained interaction with elites, opponents and authorities" (Tarrow 1994: 3-4). From this definition, we can identify a number of unique features. First, it focuses on collective challenges which involve relatively coherent groups of people. This contrasts with micro-political approaches that tend to focus on relatively individual forms of resistance such as the reinterpretation of an individual's subject position. Second, it focuses on how these collectives are held together by a sense of common purpose and solidarity. This contrasts with micro-political approaches that have largely been blind to how common purpose, senses of solidarity, or what Laclau and Mouffe call 'chains of equivalence' spring up between different groups engaged in struggle. Finally, social movement theory draws our attention to how resistance may involve sustained interaction with dominant groups such as managerial elites. This differs from micropolitical approaches that largely examine resistance as it occurs in the here and now through very specific and localized forms of engagements. By examining the patterns of sustained interaction we are alerted to how resistance may involve ongoing, collective campaigns rather than relatively short bursts of micro-political struggle. In sum, social movement theory provides us with a way to capture struggles with discourses of management that are collective, are bound together by bonds of solidarity, and are sustained across time and space.

As Laclau and Mouffe point out, social movements are vital vehicles for challenging hegemonic discourses such as management. Indeed, for them it is social movements that are central movers in taking advantage of the continually fragile nature of hegemony. 
However, all social movements are not the same. There are important differences in the way that social movements engage in hegemonic struggle. In what follows, we will argue that social movements differ crucially in terms of the strategy they follow as well as the location they choose to pursue their struggles (see Figure One). By making these distinctions, we are able to identify four ideal types of social movements that may seek to resist discourses of management.

\section{INSERT FIGURE ONE ABOUT HERE}

\section{Strategy}

The first crucial point of difference between different social movements is the strategy which they employ. Through extensive ethnographic and archival work, the anthropologist James C. Scott has identified two broad types of strategies that social movements mobilize. The first strategy is official politics that comprises all "open, declared forms of resistance” (J. Scott 1990: 198). A political strategy involves relatively open debate and conflict. This is often "the realm of elites (for example, lawyers, politicians, revolutionaries, political bosses), of written records (for example, resolution, declaration, news stories, petitions, lawsuits), and of public action” (J. Scott 1990: 200). In relation to discourses of management, this may take the form of open contestation involving elite actors, including union officials, social movement organizations and managerial cadres. This strategy depends on hierarchical modes of organization and representation. This is because the world of politics is made up of 'official channels' such as bureaucratic forms of communication and authority.

Typically, when a movement follows a political strategy, it will become embodied in a social movement organization (SMO). This is a "complex, or formal, organization that identifies its goals with the preferences of a social movement or a countermovement and attempts to implement those goals” (McCarthy and Zald 1987: 20). SMOs are typically formal, semi-hierarchical organizations which have official procedures, practices, systems of offices and a basis in law. Like other organizations, SMOs are willing to engage in official or institutionalized politics. The central task of an SMO is to articulate the multiple concerns of a social movement in a single authoritative voice within the public sphere. There are a wide range of SMOs who challenge discourses of management; these include unions (Selsky et al. 2003), environmental SMOs 
(Lounsbury 2001), micro-production communities (Hensmans 2003), consumer movements (Spicer and Fleming forthcoming), and fair-trade movements (Jaffee et al. 2004).

Social Movements will typically adopt a political strategy for a number of reasons. If the social movement has a large membership, it is likely to follow a strategy using formal, political means. This is because it is difficult, if not impossible, to co-ordinate a large mass of protestors through small group mechanisms such as informal leadership or collective decision-making (Michels 1962). We should note that there are many important exceptions to this such as large impromptu crowds inflamed by a particular issue. However, these large improvised crowds are not typically able to sustain themselves beyond a single protest event (Canetti 1962).

The characteristics of the field social movements operate in are also of importance. A field is a set of "organizations that, in the aggregate, constitute a recognized area of institutional life: key suppliers, resources and product consumers ... and other organizations that produce similar service and products” (DiMaggio and Powell 1983: 148). If a social movement operates in new or declining fields, then they will adopt a more formalized political strategy. This is because when a field is new or declining, there are few definitions of control and order that are accepted as the norm across the field (Fligstein 1996). This creates significant opportunities for social movements to formally voice their concerns in public debates and often make rapid progress (Hensmans 2003). The result is that more formalized movements can adopt a political strategy and publicly articulate their dissatisfactions without concern for established field-wide norms.

Finally, political opportunity structures also play a role in shaping the strategy that a social movement adopts. Opportunity structures are "consistent - but not necessarily formal or permanent - dimensions of the political environment that provide incentives for people to undertake collective action by affecting their expectations of success or failure" (Tarrow 1994: 85). If a social movement is faced with a relatively conducive political opportunity structure, then it will be more likely to adopt a political strategy. A conducive opportunity structure is one where there is relatively open access to participation in the dominant institutions, when political alliances are relatively 
unstable, when elite allies are available, and when the state has a relatively low propensity or capacity for repression (McAdam 1996: 27). In cases where there is a conducive opportunity structure, public attempts to challenge dominant actors will be perceived as more likely to succeed by social movements. In order to grasp the opportunity of public success, they will be more likely to mount a more organized challenge against dominant groups. In order to do this, social movement theory has shown that they are likely to adopt a political strategy. In sum, social movements will be more likely to adopt political strategies when they are large in size, when they operate in new fields and when they face conducive opportunity structures.

The second strategy that resistant groups may adopt is infra-politics. This involves less formalized and organized attempts to challenge managerial hegemony. This is "the realm of informal leadership and non-elites, of conversations and oral discourse, and of surreptitious resistance” (J. Scott 1990: 200). Such a strategy takes the form of direct and non-hierarchical attempts by actors to reconstitute social relationships and assert their rights. The accent is on direct action that is not co-ordinated through formal organizations and actively avoids engagement with official centres of power such as corporate hierarchies or the state. Instead, when actors adopt an infra-political strategy, they favour the direct claiming of rights.

When a social movement follows an infra-political strategy, it often eschews the more formal structures of a social movement organization and takes on a non-institutional form which is co-ordinated in very informal ways. At the heart of these movements is an attempt to collectively create and experiment with alternative identities, aspects of the symbolic economy and cultural innovation (Melucci 1989, 1996). Consequently, an infra-political social movement typically involve struggles for cultural recognition and justice, which includes economic, racial, gender, environmental and other issues. Also, social movements tend to lack formal, hierarchical modes of organizing and are marked by grassroots, local level network structures that mobilize resources on an 'ad hoc' basis (A. Scott 1990: 19). This means social movements are frequently characterized by purposeful anti-authoritarianism (Crossley 2002). Thus, social movements often have an 'anti-institutional orientation' and avoid modern institutionalized spheres of politics (Blaug 1998). Finally, social movements pursue an agenda of "challeng(ing) the machine of the state with viral micro-operations" (Blaug 1998: 45). This involves 
struggles in every-day life through re-appropriating identities and daily rhythms. Such social movements have been shown to play a role in contesting dominant styles in an industry (Rao et al. 2001; Rao et al. 2003), championing Gay and Lesbian causes (Creed et al. 2000), and advancing the interests of the shareholders of large corporations (Davies and Thompson 1994).

The conditions under which infra-politics thrive are the opposite of those which foster a political strategy. Relatively small movements are likely to follow an infra-political strategy. This is because if they are small, they can rely on mechanisms of small-group co-ordination and collective decision making (Breines 1989). It is not necessary for them to adopt the more hierarchical structures that are a hallmark of a political strategy. If a social movement is operating in a relatively established field, then it is more likely to adopt an infra-political strategy. This is because established fields tend to be characterized by a narrow range of participants who share common, agreed upon and accepted forms of control (Fligstein 1996). This order results in a world of where there is little space for public and formalized contestation. In order to resist patterns of domination in these established fields, informal and disorganized struggles frequently spring up and challenge apparently powerful groups. Because the formal institutions are relatively closed, groups will adopt less organized, infra-political strategies which avoid these established field wide patterns altogether.

Finally, if a social movement is faced with an un-conducive opportunity structure, then it would be more likely to adopt an infra-political strategy. Following McAdam (1996), an un-conducive opportunity structure is one where access to dominant institutions are relatively closed and difficult to access, when political alliances are relatively stable, when there are few possible elite allies, and when the state has a relatively high propensity or capacity for repression. In these situations, the perceived likelihood of succeeding is relatively low and the costs of failure are often very high. The result is that social movements will adopt an infra-political strategy involving more fluid organizational forms and direct tactical engagements. This makes it very difficult for a potentially repressive elite (e.g. a military dictatorship) to trace the movement and take revenge on movement participants. In sum, movements will tend to adopt an infrapolitical strategy if they are relatively small, operate in a relatively new institutional field, and are faced with an un-conducive political opportunity structure. 


\section{Location}

As well as employing very different strategies, social movements will seek to pursue their struggles in different spheres. Most accounts of resistance in organization and management studies have focused on resistance within the workplace. This wide ranging literature has highlighted two broad forms of struggles. Some forms of workplace movements, such as trade unions, follow a more explicitly political strategy. This means they have more formalized structures, professional officials and often engage in establish institutions. Other workplace-based movements, such as 'organizational misbehaviour', involves an infra-political strategy. This uses informal structures of kinship or friendship, eschewing movement professionals, and seeking to resist through 'direct action'. As we have already seen, these forms of workplace-based movements are a vital part of the struggles with discourses of management. This means, they should not be ignored or underestimated. Nonetheless, by only focusing on struggles within the workplace, they ignore how a whole range of groups in civil society are actively engaged in struggles with discourses of management.

Civil society actors include citizens who are, for example, outraged about the prevalence of managerial discourses in the public sector, urban inhabitants concerned with the discussions about public space being dominated by managerial concerns, agricultural producers concerned with discourses of management replacing traditional craft knowledge in farming, women groups who question the masculine bias of management discourses, and protestors distressed by the imposition of discourses of management by multinational bodies like the International Monetary Fund or the World Bank (Notes from Nowhere 2003). An adequate theory of how social movements resist discourses of management must recognize that these hegemonic struggles do not only take place on the shopfloor. They also take place on the streets, in public meetings, in the media, in education, in consumption practices and in people's everyday lives. In short, struggles against the discourses of management take place in civil society as well as in the workplace. This means an adequate theory of movements against discourses of management needs to take into account two movement forms: those which focus their struggles with management in the workplace, and those which focus their struggles in civil society. In what follows, we shall detail the unique features of each location. 
As we have already argued, the most well documented location of resistance to discourses of management is the workplace. The extensive literature on unionized resistance and organizational misbehaviour focuses on how workers resist the imperatives of management within the constraints of the wage labour or employment relationship. This resistance may pertain more directly to the terms of the employment relationship such as the distribution of resources within an organization or trade. Examples of struggle over such resources are unionized claims for higher wage levels (Hyman 1973) or more direct appropriation of goods through theft (Mars 1982). Resistance in the workplace might also challenge the distribution of status and articulation of identity within the workplace. Examples include unions articulating strong trade-based pride and solidarity (Thompson 1967) and cynical asides which seek to degrade the status of management (Collinson 1992; Fleming and Spicer 2003). Finally, resistance within the workplace might involve challenging company policies that constrain work practices and creativity. An excellent example of this is bureaucratic insurgencies by mid-level employees who question company policies (Zald and Berger 1977). In each of these cases, actors may target discourses of management in order to (momentarily) change the distribution of resources, status, or policies. What is crucial is that these challenges take place in existing employment relations.

The workplace remains an important focus for movements engaged in struggles with discourses of management. The location of resistance in the workplace is mediated by the availability of space to engage in acts of resistance in the workplace. We are likely to see resistance occur in the workplace when it provides spaces for this resistance to occur. These spaces might be opened by formal mechanisms such as liberal labour laws, union friendly company policies or high degrees of autonomy in the labour process. They might also take the form of informal spaces of everyday life created by incomplete surveillance and ingenious methods of avoiding surveillance. These would allow a zone where it is possible to challenge discourses of management. Struggles are also likely to well up in the workplace when discourses which directly effect the labour process are at work (Edwards 1979). These discourses of management include Total Quality Management (Sewell and Wilkinson 1992), just in time (Knights and MacCabe 2000), and corporate cultures (Collinson 1992). These discourses shape how much time is spent at work, the organization of the actual work itself, the allocation of products of that work, and the occupational identities that result from work. When questions arise 
around these issues we might expect to find various forms of social movements welling up in the workplace. For instance, unions seek to call into formal question managerial claims of control over the labour process through strike actions (Hyman 1973). Similarly, more informal, infra-political workplace movements may seek to subtly challenge discourses of management through more hidden forms of action such as antimanagement humour (Taylor and Bain 2002). But what is at stake in both these situations is the question of who controls the labour process. In sum, resistance to managerial hegemony is likely to be located within the workplace when the employment relationship allows spaces for contestation and when the central issue is control over the labour process.

The workplace remains a vital zone for movements seeking to resist discourses of management. However, many of the serious challenges that face organizations today come from movements based in the wider realms of civil society. Civil society is a sphere of social interaction that is separated from the family, state and marketplace (Hegel 1821/2002). Unlike the family or the marketplace which are governed by the language of biological necessity and efficiency, civil society is governed by political reason which involves attempts to change the relations between humans (Arendt 1958). It is also the sphere where the supposedly savage natural passions of man are civilized and ordered (Hobbes 1651/1985; Elias 1939/2000). Finally, although civil society may be structurally separated from the state and the economy, in political practice civil society offers the vital ideological 'ground work' that establishes those structures of social and cultural consent that support, and enable the reproduction of, the state and the economy (Gramsci 1971).

Struggles against managerial discourses in civil society become important when workplaces provide few spaces for resistance to express grievances. Some conditions which have reduced the space for struggle within the workplace would include labour laws that discourage union activities and surveillance regimes that provide little opportunity for resistance or impromptu innovation. An obvious case where employees flee the constrictions of the firm to voice their concerns in civil society is whistleblowing (Perry 1998). The anti-sweatshop campaign is another example of a struggle that first appeared in civil society. These sweatshop factories are taken by their 
opponents to be the result of the unconstrained propagation of discourses of management.

However, civil society is not simply an alternative location for workplace struggles. Following Gramsci (1971), hegemonic regimes are always legitimized through powerful consent structures in the wider realms of civil society. That is, economic and managerial discourses will be accompanied by specific social and cultural consent structures that help to reproduce what Gramsci called 'hegemonic blocs'. Thus, civil society becomes an important locus of resistance when the legitimation process of management is at stake (Poggi 2001: 58-73). This legitimation process is how certain practices, mindsets and discourses come to be considered as acceptable, correct and inevitable (DiMaggio and Powell 1991). Dominating civil society discourses is so important for hegemonic elites because it is here where this process of legitimating management is played out. For instance, social movements like Greenpeace have sought to challenge the legitimacy of the activities of large companies by using public protests and the media (Tsoukas 1999). Similarly, consumer rights organizations sought to challenge the legitimacy of large industrial corporations by exposing the poor quality of their products (Rao 1998). In both these cases, the movements entered into civil society spaces such as the media in order to challenge existing patterns of legitimacy or develop new ones. In sum, resistance against managerial discourses is likely to be located in civil society when there are few spaces for resistance within an employment relation and when the central issues at stake is control of the legitimation process of management.

\section{A Model of Social Movement Resistance}

So far, we have argued that resistance movements differ in terms of their location (workplace or civil society) and strategy (political or infra-political). Bringing these two dimensions together provides a typology of four different ideal types of resistance movements: political movements located in the workplace, infra-political movements located in the workplace, political movements located in civil society, and infra-political movements located in civil society (See: Figure Two). In what follows we shall explore each of these ideal types in turn. 
The first kind of resistance movement involves formally organized political groups located in the workplace. We shall call this organized workplace resistance. This involves contesting discourses of management in the workplace. These movements pursue their aims through formal, organized political processes. We would expect these movements to appear when they are relatively large in size, exist within a new or declining field, face a conducive opportunity structure, are located in a workplace where there is sufficient space for workplace conflict, and when control over the labour process is the central issue at stake. The paradigmatic example of such resistance is the workplace unionism (Kelly 1998).

The second kind of resistance movement involves infra-political resistance in the workplace. We shall call this organizational misbehaviour (see also Ackroyd and Thompson 1999). This kind of movement also seeks to engage discourses of management in the workplace, but does so through more informal and disorganized networks. This mode of resistance tends to arise when employment relationships provide informal opportunities for conflict, when control over the labour process is at stake, when the resistance movement is relatively small in size, when it exists in an established field, and when resistant parties face relatively un-conducive opportunity structures. The paradigmatic example of organizational misbehaviour is cultures of workplace cynicism (Fleming and Spicer 2003).

The third ideal type of resistance movement involves political movement organizations which are located in civil society. Usually these resistance organizations would be referred to as social movement organizations (SMOs). However, in order to distinguish them from SMOs in the workplace such as unions, we shall refer to them here as Civic Movement Organizations (CMOs). These movements seek to challenge discourses of management in spaces outside the employment relationship such as public protests, the media, public debates and education. This contestation proceeds through formally organized social movement organizations which often have official representatives. We would expect to find this kind of resistance movement when it is of a relatively large size, addresses a new field, is confronted with a relatively conducive opportunity structure, there is little opportunity for workplace resistance, and the central issues at stake are related to processes of legitimation. The paradigmatic example of this kind of 
movement is a civil society focused social movement organization like Greenpeace (Tsoukas 1999).

The final ideal type of resistance movements that engage with discourses of management are those that focus their efforts in civil society but adopt infra-political strategies. Typically, these movements would be referred to as social movements. But in order to clarify the distinction between movements in civil society and those in the workplace, we shall call them civic movements here. Like their more politically focused cousins, civic movement organizations, these forms of civil society resistance seek to populate spaces outside the workplace. However, they adopt more ad-hoc or loosely organized forms to express their discontents. This type of resistance movement will tend to arise when movements are of relatively small size, exist in a mature field, face an unconducive opportunity structure, have few opportunities to engage in struggles at work and focus their concerns around issues of legitimation. The paradigmatic example of this type of resistance is a civil society based social movement such as the 'antiglobalization’ movement (Chesters and Welsh 2006).

The various categories we have outlined above are ideal types of resistance (Rich 1992). The principal use of such categories is to analytically distinguish different modes of organizational resistance that have been discussed in the literature. This is to say, these categories should not be seen as essential. Rather, they provide a heuristic tool for clarifying the unique aspects of each mode of resistance and help to comprehend how each mode of resistance relates to one another. By doing this we provide a framework that allows researchers to consider the multiple forms of resistance to managerial hegemony.

\section{Combinations of Resistance}

Above we have detailed four ideal types of resistance movements. At this point it is important to highlight the blurred boundaries between these ideal types. Clearly, any empirical study of patterns of resistance to discourses of hegemony of management would significantly blur the boundaries between different types of resistance. Laclau and Mouffe (1985) suggest hegemony is never constituted in a singular place. Indeed, the reason discourses of management have been so successful is that they have been 
able to establish their dominance in both the workplace and civil society; in the formal workings of organizational life and the more informal identities and patterns of daily behaviour. This suggests that struggles against management as hegemonic discourse might also be distributed across multiple domains (Levy and Scully 2007). So, perhaps what is more interesting than the various ideal types of resistance are the processes of blurring and interaction which occur between them. Let us therefore briefly consider the various processes of interchange and blurring between different types of organizational resistance.

\section{Civic Movement Organizations and Civic Movements}

In many cases there is a clear symbiosis between civic movements and civic movement organizations (CMOs). It is as if the civic movement provides the energy and legitimacy for many civic movement organizations. Indeed, the more staid strategies followed by civic movement organizations are often bolstered by a 'radical flank' (Haines 1988). Similarly, CMOs often provide a clear focal point for developing and debating issues that movements wish to call attention to. For instance, the environmental movement clearly underpins, and lends legitimacy to, the many high-profile CMOs such as Greenpeace. However, organizations like Greenpeace often directly speak for this movement, without necessarily being able to represent the multiple positions held within that movement. Some civic movements clearly become more organized and more integrated into institutions of public politics, consequently becoming CMOs. Greenpeace, for example, emerged out of the environmental movement of the 1970s and early 1980s, which also produced the Green Parties in various European countries. In many cases this process of institutionalization can sap civic movements of their radical and transformative drive by incorporating them into existing institutional structures (Piven and Cloward 1979). Alongside this institutionalization process is a deinstitutionalization process whereby activists within CMOs may become disheartened with the ossified nature of institutionalized politics. They may engage in a process of giving transformative voice to the organization. They may also exit the organization and seek to satisfy their radical desires within more loosely organized civic movements.

\section{Organizational Misbehaviour and Unions}

Like the relationship between CMOs and civic movements, the relationship between organizational misbehaviour and unionized workplaces is marked by different political 
strategies and degrees of institutionalization. The interaction between unionism and organizational misbehaviour has been hotly debated within industrial sociology (Sewell and Wilkinson 1992; Thompson and Ackroyd 1995; Fleming and Sewell 2002). One of the central arguments we find in this literature is that the day-to-day acts of resistance against discourses of management often provide the foundations of antagonistic attitudes and actions that are given an organized and systematic expression by unions. Some studies show that unions enthusiastically draw upon modes of organizational misbehaviour such as humour and cynicism in their struggles against discourses of management (Rodrigues and Collinson 1995). We have also seen that, as unions become increasingly ossified and incorporated into managerial strategies and state policy, workers become disheartened with their ability to act as agents of radical change (Hyman 1973). This often leads to a process were workplace resistance becomes deinstitutionalized and takes the form of more uncontrolled attacks on discourses of management such as wild-cat strikes, unofficial action and organizational misbehaviour.

\section{Unions and CMOs}

Links and alliances between unions and CMOs are possible and frequently occur. What is more interesting perhaps is when each organization begins to address issues that are typically associated with its opposite number. Union organizations, for example, frequently address civil society issues such as identity politics. When unions take up issues in civil society we might say they are taking on CMO functions. Similarly, CMOs may address workplace issues that have traditionally been represented by unions. For instance, some struggles for social justice in American cities such as the 'living wage’ campaign have increasingly engaged discourses of management around issues such as wages and working conditions (Luce 2005). What we can generally observe is that the historically separated realms of workplace politics and civil society have become increasingly blurred, as unions aim to move beyond their traditional location in the workplace and CMOs see civil society now as including the politics of work, wages and economic justice.

\section{Unions and Civic Movements}

One of the central questions in the contemporary union movement and amongst the socalled 'new left' is whether civic movements are increasingly replacing unions as the central vehicles for expressing struggling against management. This has led some in the 
union movement to argue that unions should align themselves with civic movements or adopt some of the strategies typically used by these movements. For the union movement to become more like civic movements requires the extension of their struggles against discourses of management into civil society by broaching issues such as identity, housing, education, and culture. It also involves unions adopting more infrapolitical means of organizing by favouring informal, kinship and community networking over formalized bureaucracies. Moreover, unions may see the grounds of struggle shift from official discourses of management to unofficial manifestations of these discourses. Examples of unions adopting strategies associated with civic movements are the garment workers justice movements and community-based unionism who seek to engage discourses of management in particular localities (Brecher and Costello 1994). Similarly, civic movements may seek to formalize their activities into organizations that publicly address issues in the workplace. This would involve institutionalizing the informal relationships which make up the civic movement and shifting the focus of struggle to the workplace. An example of this shift is the gay and lesbian movement challenging homophobic strains in discourses of management by campaigning for the rights of gay and lesbian people (Creed and Scully 2000) and other ‘diverse’ groups (Scully and Segal 2000) in the workplace.

\section{Civic Movements and Organizational Misbehaviour}

Both civic movements and organizational misbehaviour are infra-political strategies of resistance, and tend to share similar tactics such as the use of humour, 'culture jamming', and network-based resistance. They contrast to the extent that civic movements address discourses of management in civil society and organizational misbehaviour tends to address and give expression to antagonisms to discourses of management in the workplace. At some point, however, organizational misbehaviour might connect with and spill over into civil society. An excellent example of this is whistle-blowing (Perry 1998). This involves an employee calling attention to challenging the infallibility of management in civil society forums such as the media. The most recent high-profile case of whistle-blowing was the auditor who publicly disclosed accounting irregularities in the now defunct utilities company, Enron. In a similar fashion, civic movements might spill over or link up with misbehaviour in the workplace. For example, members of a movement campaigning for the preservation of public services may engage in clandestine acts in the workplace aimed at sabotaging the 
introduction of enterprise culture into public sector workplaces. These may range from potentially devastating acts like whistle-blowing to more mundane acts like defacing and 'jamming' enterprise culture. In each of these cases, civic movements and organizational misbehaviour may mutually reinforce each other.

\section{Organizational Misbehaviour and CMOs}

The final possible linkage across different forms of resistance is between infra-political antagonisms with discourses of management in the workplace and public antagonisms in civil society. As we saw above, it is possible that informal discontent and misbehaviour in the workplace can spill over into civil society. This would typically occur when resistance hits upon issues located outside the workplace. For instance, discontent about managerial discourses in one's own workplace may spill over into concerns about the rise of managerialism in public services. The discontent and antagonism may be expressed through civic movement tactics such as informal protests about public service closures, but it may also be taken up by, or transformed into, a more formal and institutional articulation through an CMO. We might find a backflow effect whereby CMO strategies may reinforce, or give legitimacy to, acts of organizational misbehaviour. For instance, we would expect that a member of an environmentally focused CMO would be more likely to engage in acts of organizational misbehaviour if their employer place emphasis on managerial discourses which are linked to environmentally destructive practices. The flipside of this is that if a CMO becomes increasingly ossified and institutionalized, members may engage in acts of organizational misbehaviour targeting the CMO - as a workplace - itself. This may involve actors sabotaging political processes, removing consent, questioning the organizational culture, and in extreme cases engaging in embezzlement and corruption. This may in turn make the CMO's official articulation of resistance an object of resistance itself.

\section{Organizational Processes of Counter-hegemony}

The above discussion of the various interchanges and blurring between different resistance movements highlights the fact that struggles against discourses of management are rarely singular. Instead, they typically involve interaction between different kinds of resistance movement (see also Levy and Scully 2007). However, the 
question remains: how exactly do these interactions take place? Following Laclau and Mouffe (1985), we would like to argue that, first, there are different forms of interaction between modes of resistance, and, second, that various forms of resistance may be in conflict with each other. For instance, civil society organizations who are concerned with the impact of discourses of management on the natural environment might come into conflict with workplace unions who are concerned with challenging management discourses in the workplace. These conflicts between different forms of resistance involve what Laclau and Mouffee (1985) call a 'logic of difference'. Such conflict between different forms of resistance is likely when the field, in which resistance takes place, is relatively well established (Hensmans 2003). In these well established fields well entrenched identities will tend to divide existing forms of resistance. However, younger fields are more likely to be more amenable to co-operating with other forms of resistance. This involves the formation of what Laclau and Mouffe (1985) call a 'logic of equivalence'. This logic of equivalence is established when 'chains of equivalence' are created between different groups who seek to challenge a hegemonic discourse. This involves the construction of a certain sameness among resisting actors resulting in a united political identity (an 'us') as well as a common enemy (a 'them'). These chains of equivalence allow what are apparently separate movements to develop some sense of commonality. While Laclau and Mouffe (1985) are clear about the strategic importance of developing chains of equivalence between different struggles, they do not detail the specific organizational processes through which these chains of equivalence are formed between different movements. To trace out exactly how chains of equivalence are established we shall discuss three organizational processes - institutionalization, escalation and affinity - through which linkages between social movements are formed.

\section{Institutionalization}

As we discussed above, one possible combination of movements involves infra-political movements - such as organizational misbehaviour and civic movements - linking up with more political and formally organized movements. Chains of equivalence between political and infra-political movements are typically forged by creating a similar mobilizing structure. These mobilizing structures are "those collective vehicles, informal as well as formal, through which people mobilize and engage in collective action” (McAdam, McCarthy and Zald 1996: 3). The purpose of these mobilizing structures is to provide an organized link between the centre and periphery of a social 
movement (Tarrow 1994: 135-150). Mobilizing structures may take on a range of forms including pre-existing informal networks in places such as the workplace, neighbourhoods as well as friendships.

However, in many cases infra-political movements become linked to more formalized strategies of political movements through formal mobilizing structures. An infrapolitical movement in the workplace, such as a culture of anti-management humour, might become linked to a more formal political organization such as a union (Rodrigues and Collinson 1995). The result is a process of institutionalization whereby the various parts of the movement become more formally organized and often more conservative (Michels 1962). Following the theoretical framework we laid our earlier, opportunities for institutionalization would arise when a movement grows to a certain size as informal relationships often cannot handle the organizational complexities of sustaining largescale collectives (Michels 1962). We would also expect there to be opportunities for institutionalization when the field that a social movement is operating in a relatively new field with few common and accepted standards and many players (Fligstein 1996). This would provide sufficient space for a social movement to establish its own norms as the field-wide lingua-franca. Finally, we would expect that movements would be able to become more institutionalized when they face more conducive opportunity structures which allow space to pursue their claims through formal organizations (McAdam 1996). These insights have been reinforced by recent work on protest cycles which charts the transition of social movements from relatively isolated protests to mass movements through formal institutionalization and ossification (Tarrow 1994). Under these conditions, we would expect that movements who had been seeking to challenge discourses of management through infra-political means would be tempted to align themselves with larger, more formalized social movement organizations. The result would be that these infra-political movements would become more formalized and institutionalized.

The ATTAC movement, ${ }^{2}$ which is one of the most outspoken critics of the global reach of management discourses, is a good example of this process of institutionalization.

\footnotetext{
${ }^{2}$ ATTAC stands for Association for the Taxation of Financial Transactions in the Aid of Citizens. It has become a global network of independent groups which comprises more than 84,000 members (www.attac.org). ATTAC campaigns in particular on issues concerning the democratisation of global
} 
Being built on a global network of mostly student-led, informal and semi-formal cells adopting infra-political forms of struggle and resistance, the ATTAC movement has quickly moved to become one of the most influential critics of international finance institutions (IFIs) which propagate managerial discourses such as the International Monetary Fund (IMF) and the World Bank (Dowling 2005). As the movement grew larger in scale, however, some groups have adopted more formal, institutionalized characteristics by involving professional campaigning staff and engaging in formal political struggles within specific national contexts; in fact, ATTAC France now operates almost like a political party (Ancelovici 2002). This process of institutionalization has alienated a number of original activists as well as new joiners because of excessive deliberation, bargaining and hierarchical structures which make it more difficult to participate in the political process. Thus, while on one hand ATTAC seems to be institutionalizing its organizational processes (through establishing a 'logic of equivalence'), this institutionalization is also resisted by some movement participants.

The ATTAC example shows that, as struggles against discourses of management become more ossified, some activists might seek to de-institutionalize their movement and return to more infra-political modes of resistance. This would involve establishing a logic of difference by splintering from the more formal setting and pursuing less organized and formalized forms of protest. Following the theoretical framework that we laid out earlier, movements might seek to de-institutionalize when they find they are shrinking in numbers thus allowing a more informal and close knit way of organizing protests. Also struggles against discourses of management may seek to deinstitutionalize when the field they operate in is becoming increasingly ossified and dominated by a narrow set of norms. The result is that marginal players might be likely to escape from this highly ritualized field (Fligstein 1996). Finally, we would expect that groups might adopt more infra-political strategies when opportunity structures become less conducive and the space to formally challenge discourses of management recedes. By adopting these more informal modes of organizing, smaller sized resistance groups would be able to negotiate their way around the closed ranks of the elite. For instance, some groups involved in struggles with managerial environmental policies 
have become dissatisfied with formal political processes and have adopted so-called 'guerrilla' tactics of direct action (Plows 2006).

\section{Escalation}

In addition to links being forged between political and infra-political movements, our above framework has laid out the possibility for movements to also forge connections between workplace based movements and civil society based movements. These linkages are typically forged through issue frames which span the boundaries of each of these spheres. These frames are "action-oriented sets of beliefs and meanings that inspire and legitimate the activities and campaigns of a social movement organization” (Benford and Snow 2000: 614). These frames provide a pattern which aids collective understanding and interpretation of a common issue. When movements share a common set of issue frames, then they begin to interpret and talk about their grievances, goals, and tactics in a common fashion. In short, a shared frame provides movements with a common mindset and a common tongue. The rise of a shared frame means that movements in two different spheres may be able to craft a common lexicon for thinking and talking about their own grievances, goals and tactics (Lounsbury et al. 2003).

The result of links being forged by common issue framing is a process of escalation. A classic instance of escalation occurs when workplace movements seek to take their struggle into the broader realms of civil society. This happens when a workplace movement begins to use civil society frames (such as 'human rights') in addition to frames associated with the workplace (such as 'fair wages'). Following the theoretical framework we outlined earlier in the paper, we would expect this to occur when a movement finds few spaces in a workplace to voice their grievances, and issues of the broader legitimacy of management discourses are at stake. In these situations, a workplace movement will seek to escalate their struggle into civil society. By doing this they will be able to access a far larger audience, and engage with broader issues than if their struggle had only been located in the workplace. An excellent example of the escalation of workplace struggles into civil society is the recent campaign for 'living wages' (Luce 2005). This campaign involves an explicit attempt by the movement to avoid the highly hierarchical bargaining structures of low-paid workplaces and focus on making direct attacks on discourses of management in civil society. They do this by using broader frames of social justice in addition to the more specific framings of fair 
wages in the workplace. In providing a broader framing of the impact of discourses of management on low wage employees, activists are able to transform the fair wage campaign from being a workplace movement to a civil society movement.

Escalating the demands of a movement to the level of civil society allows groups to establish a logic of equivalence between what were previously different locations of resistance. However, this sometimes shifts the focus of the movement too far away from the issues directly associated with the workplace. The result may be that the movement's voice is less likely to be directly incorporated into organizational decisionmaking. This means that to increase influence within established organizational settings, resistance groups in civil society may be tempted back into using the language of the workplace. This would involve a movement trading broader civil society frames such as 'social justice' for more specific workplace frames such as 'organizational effectiveness'. The result would be a de-escalation of the movement and the rise of a logic of difference. Following the theoretical framework outlined earlier, we would expect that this de-escalation might occur when sufficient space is available in the workplace to engage with managerial policies and when issues directly pertaining to the labour process are at stake. In these instances, activists will seek to use their workplace as a space to launch challenges to the status quo, but will also be necessary constrained by the demands of management. An excellent example of such a process of deescalation is the shift in strategy of some aspects of the gay, lesbian, transgender and bisexual (GLTB) movement. Initially, this movement sought to challenge the homophobic nature of management discourses by articulating broader civil society frames such as 'gay rights as civil rights' and focus on changing the legal status of gay employees (Creed et al. 2002). The movement then turned to the workplace and emphasized work specific frames such as ‘competitive advantage' (Creed et al. 2000). The movement sought to get its message across through everyday encounters and workplace lobbying (Creed et al. 2000; Scully and Segal 2000). These encounters were aimed at changing the specific interactions within the workplace rather than pursuing broader goals of changing laws. Nonetheless, workplace activists interpreted these engagements as a smaller part of the broader struggle for gay rights. Further, they were acutely aware that prior struggles in civil society had smoothed the way for them to challenge what they saw as some of the more heterosexist biases implicit in the discourses of management in the workplace. 


\section{Affinity}

The processes of institutionalization and escalation both create logics of equivalence between different forms of resistance. They also both involve a transformation of these different forms of resistance through the reordering of these links. For instance, when links are forged between infra-political and political forms of resistance, we have argued that often the movement begins to take on a more formal character. Similarly, when workplace movements seek to escalate their struggle into civil society, they often shift the focus of their activities. In both cases, the creation of hegemonic links between different movements leads to the effective dominance of one strategy over another. Institutionalization involves the dominance of political strategies over infra-political strategies, and escalation involves the dominance of civil society strategies over workplace strategies. The result is often bitter disputes and disillusionment of many movement members who either value less formalized ways of protesting or prefer to focus their activities on the workplace.

However, forging links does not always involve one form of resistance dominating other forms. There are many cases where movements are linked together in a common struggle without adopting collective identities and strategies. Instead, these loosely linked movements maintain relatively specific and unique identities and pursue their own strategies. In these cases the groups are often linked together by collective emotions. These are "complexes of processes-in-relations that are transpersonal in scope and that consist in psychical investments, engagements, or cathexes, where these encompass embodied perceptions and judgments as well as bodily states, forces, energies, or sensations” (Emirbayer and Goldberg 2005: 472). Collective emotions play an important role in holding social movements together through similar patterns of affect and resonances (Aminzade and McAdam 2001, Goodwin et al. 2001). These patterns of collective emotion link together those who feel the same about a particular issue even though they may engage with that issue in radically different ways. These collective emotions might hold groups together by forming patterns of attachment and feelings of solidarity between different members of a group. This creates an emotional sense of an 'us'. Collective emotions also hold groups together by structuring common patterns of aversion and aggression towards enemies. This creates an emotively charged 
sense of a 'them'. The upshot is that a logic of equivalence can be crafted between quite different protest groups.

The result of collective emotions between different groups pursing divergent strategies leads to loose co-ordination which recent commentators refer to as affinities (Day 2004). These common patterns of emotion would result in affinities springing up between infra-political and political movements, as well as workplace and civil society movements. Following the framework outlined earlier in the paper, we would expect these patterns of affinity to spring up when movements face paradoxical situations. For instance, affinities between workplace and civil society movements might spring up when both the workplace and civil society provide space for contestation, or there are issues associated with the labour process as well as the legitimation process at stake. Similarly, affinities may spring up between political and infra-political movements when the issue at stake involves small scale as well as larger scale actors, span established as well as new fields, and involve a 'mixed' opportunity structure that may be both conducive as well as oppressive to movements in different situations. For instance, successful environmental campaigns often involve a range of different modes of resistance around particular issues (Della Porta and Rucht 2002). Institutionalized politics such as lobbying, publicity drives and legal actions exist alongside more infrapolitical actions such as snap protests, occupations and sabotage. What is particularly interesting here is that an implicit 'division of labour' might arise between resistance groups, with each group making use of their unique strategies and location to address a common issue. We might hypothesize that these quite different struggles are held together by similar patterns of emotion. This suggests that resistance groups may be able to engage in collective action against discourses of management without necessarily adopting a single strategy when they are bound together by similar patterns of affect.

For a movement to challenge hegemonic discourses of management it cannot remain singular and local. This is often not recognized in organization and management studies, as researchers have increasingly highlighted the importance of particular modes of resistance such as micro-political resistances in the workplace (Thomas and Davies 2005). What our model aims to show is that resistance movements involve a multiplicity of forms that occurs in both the workplace and civil society. For 
movements to be effective and successful, they need to be able to transit between political and infra-political strategies of resistance and civil society and the workplace as the location of their resistance. This suggests that the most interesting modes of resistance are combined or hybrid forms of struggle. This is achieved through developing common mobilizing structures, crafting issue frames which cross social spheres, and propagating collective emotions. It is these processes which may give rise to logics of equivalence that could effectively challenge the well entrenched discourses of management. However, we should be mindful that the interaction of different forms of resistance can also give rise to a logic of difference whereby forms of struggle are driven apart.

\section{Conclusions}

In this paper we have sought to explore how discourses of management are resisted. We have argued that current approaches that examine 'micro-political' forms of resistance in the workplace tend to ignore the collective strategies of resistance occurring in a multiplicity of spheres in civil society. In order to address this lacuna, we have argued that resistance targeted against discourses of management may be thought about as social movements. Drawing on social movement theory, we argued that movements differ in terms of the strategy they follow (political or infra-political) and the location of the struggle (workplace or civil society). This framework identifies four ideal types of movements that engage with discourses of management. While each of these movements are important, perhaps the most interesting forms of resistance involve novel and interesting connections being crafted between different movements in order to create a logic of equivalence between different struggles. We argued that these novel connections between movements are established through creating common mobilizing structures, common issue framing, and collective emotions.

The theoretical framework offered in this paper makes a number of contributions to the study of resistance in organization and management studies. First, we chart out a way to move beyond the current focus on micro-political forms of resistance in the workplace. We do this by arguing that it may be more advantageous to think about resistance as a movement. This allows us to capture the fact that many forms of resistance to discourses of management are often collective and often engage far broader issues than 
immediate conditions in the workplace. Examining resistance as a movement also alerts us to the fact that struggles against the discourses of management do not just take place in the workplace. Rather, struggles may also be mounted in civil society. Thus, our framework helps to sensitize scholars of resistance to the whole range of movements in the workplace and civil society that actively engage discourses of management. By conceiving resistance as a movement, we hope to invite future empirical work that considers the wide range of collective challenges to discourses of management.

The second contribution this paper makes to the study of resistance is to chart the possible interactions which might exist between different forms of resistance movements. By examining these interactions, we have pointed to the fascinating combinations of resistance involved in contesting management and opened up a space for conceptualizing the organizational processes involved when creating counterhegemonic blocs against managerial discourses. This framework now invites detailed empirical work to study the organizational processes of combining different types of resistance. Some questions which could be investigated include: which combinations are more common in which particular contexts; what is the success rate of each combination of resistance; how are the organizational links made between different types of resistance; how do hybrid modes of resistance emerge; and how do chains of equivalence between different forms of resistance fall apart?

Rather than privileging one resistance movement over another, our main aim has been to argue for the necessity of recognizing that various forms of resistance against discourses of management coexist alongside each other in different spheres of society. However, this is not thought of as a 'pick and mix' model. Instead of providing a relativistic multi-paradigm model of resistance movements, we have discussed the internal antagonisms and contradictions as well as dialectical relationships between different movements. If anything, this paper has tried to contribute to a better understanding of the multiple aporias that exist between the constant need for movements to organize and institutionalize, and the equally pressing need for movements to overflow institutionalization. In our view, what is now urgent for organization and management researchers is to abandon their pre-occupation with struggles occurring in the workplace and also consider the multiple resistances against managerial discourses taking place in the wider realms of civil society. What is crucial 
is to study the ways strategic links between different movements can be made in order to organize counter-hegemonic blocs that are able to effectively challenge the hegemony of managerial discourses. 


\section{References}

Ackroyd, Stephen and Paul Thompson

1999 Organizational misbehaviour. London: Sage.

Ancelovici, Marcos

2002 'Organizing against globalization: The case of ATTAC in France'. Politics and Society 30/3: 427-463.

Arendt, Hannah

1958 The human condition. Chicago: University of Chicago Press.

Ball, Kirtsy and David C. Wilson

2000 'Power, control and computer-based performance monitoring: Repertoires, resistance and subjectivities’. Organization Studies 21/3: 539-565.

Bensman, Joseph and Israel Gerver

1963 'Crime and punishment in the factory: The function of deviance in maintaining the social system’. American Sociological Review 28/4: 588-598.

Blaug, Ricardo

1998 'The tyranny of the visible: Problems in the evaluation of anti-institutional radicalism'. Organization 6/1: 33-56.

Böhm, Steffen

2006 Repositioning organization theory: Impossibilities and strategies. Basingstoke: Palgrave.

Braverman, Harry

1974 Labor and monopoly capital: The degradation of work in the twentieth century. London: Monthly Review Press.

Brecher, John and Tim Costello 1994 Global village or global pillage: economic reconstruction from the bottom up. Boston: South End Press.

Breines, Wini

1989 Community and organization in the new left, 1962-1968: The Great Refusal. New Brunswick, NJ: Rutgers University Press.

Brown, Geoff

1977 Sabotage. Nottingham: Spokesman.

Brown, Andrew D. and Christine Coupland

2005 'Sounds of silence: Graduate trainees, hegemony and resistance'. Organization Studies 26/7: 1049-1069.

Burawoy, Michael

1979 Manufacturing consent: Changes in the labour process under monopoly capital. Chicago: University of Chicago Press. 
Canetti, Elias

1962 Crowds and power. London: Phoenix.

Carter, Chris, Martin Kornberger and Stewart Clegg

2003 'The Polyphonic spree: the case of the Liverpool dockers'. Industrial Relations Journal 34/4: 290-304.

Chesters, Graham and Ian Welsh

2006 Complexity and social movements: Protest at the edge of chaos. London: Routledge.

Chiapello, Eve and Norman Fairclough

2002 'Understanding the new management ideology: a transdisciplinary contribution from critical discourse analysis and new sociology of capitalism'. Discourse and Society 13/2: 185-208.

Clawson, Dan and Mary Ann Clawson

1999 'What has happened to the U.S. labor movement? Union decline and renewal'.

Annual Review of Sociology 25: 95-119.

Clemens, Elisabeth

1993 'Organizational repertoires and institutional change: Women's groups and the transformation of American politics, 1890-1920'. American Journal of Sociology 98/4: 755-98.

Cole, G. D. H.

1917 Self-government in industry. London: Hutchison Education.

Collinson, David

1992 Managing the shop-floor: Subjectivity, masculinity and workplace culture. Berlin: de Gruyter.

2003 ‘Identities and Insecurities: Selves at work’. Organization 10/3: 527-547.

Contu, Alessia

2002 'A political answer to questions of struggle'. ephemera: critical dialogues on organization 2/2: 160-74 [www.ephemeraweb.org].

Contu, Alessia and Hugh Willmott

2003 'Re-embedding situatedness: The importance of power relations in learning theory’. Organization Science 14/3: 283-96.

Creed, W. E. Douglas and Maureen A. Scully.

2000 'Songs of ourselves: Employees' deployment of social identity in workplace encounters’. Journal of Management Inquiry 9: 391-412.

Creed, W. E. Douglas, Maureen A. Scully and John R. Austin

2002 'Clothes make the person: The tailoring of legitimating accounts and the social construction of identity’. Organization Science 13: 475-496. 
Crossley, Nick

2002 Making sense of social movements. Buckingham: Open University Press.

Crouch, Colin

2005 Capitalist diversity and change: Recombinant governance and institutional entrepreneurs. Oxford University Press.

Dahl, Robert

1957 'The concept of power'. Behavioural Science 2: 201-205.

Davis, Gerald and Tracy A. Thompson

1994 'A social movement perspective on corporate control'. Administrative Science Quarterly 39/1: 141-173.

Davis, Gerald, Doug McAdam, W. Richard Scott, Mayer N. Zald, eds.

2005 Social movements and organization theory. Cambridge, UK: Cambridge University Press.

Day, Richard J. F.

2004 'From hegemony to affinity: The political logic of the newest social movements'. Cultural Studies 18/5: 716-748.

Deem, Rosemary

1998 'New managerialism and higher education: The management of performance and culture in universities in the UK'. International Studies in the Sociology of Education 8/1: 47-70.

della Porta, Donatella and Mario Diani

1999 Social movements: An introduction. Oxford, Basil Blackwell.

Della Porta, Donnatella and Dieter Rucht

2002 'The dynamics of environmental campaigns’. Mobilization 7/1: 1-14.

DiMaggio, Paul and Walter W. Powell

1983 'The iron cage revisited: Institutional isomorphism and collective rationality in organizational fields'. American Sociological Review 48: 147-160.

1991 'Introduction' in The New Institutionalism in Organizational Analysis. W. W.

Powell and P. J. DiMaggio (eds). Chicago: University of Chicago Press.

Disney, Richard, Amanda Gosling and Stephen Machin

1995 'British unions in decline - determinats of the 1980s fall in union recognition'. Industrial and Labour Relations Review 48/3: 403-419.

Ditton, J.

1972 'Absence at work: How to manage monotony’. New Society 21: 697-681.

Doolin, Bill

2002 'Enterprise discourse, professional identity and the organizational control of hospital clinicians’. Organization Studies 23/3: 369-390. 
Dowling, Emma

2005 'The ethics of engagement revisited: Remembering the ESF 2004'. ephemera:

theory \& politics in organization 5/2: 205-215.

Elias, Norbert

1939/2000 The civilizing process, $2^{\text {nd }}$ ed. Oxford: Blackwell.

Elliott, Carole

2003 'Representations of the intellectual: Insights from Gramsci on management education’. Management Learning 34/4: 411-27.

Emirbayer, Mustafa and Chad Alan Goldberg

2005 'Pragmatism, Bourdieu, and collective emotions in contentious politics'. Theory and Society 34: 469-518

Eikenberry, Angela M. and Jodie Drapal Kluver

2004 'The marketization of the non-profit section: Civil society at risk?'. Public Administration Review 64/2: 132-140.

Fairclough, Norman

1995 Critical discourse analysis. London: Longman.

Foucault, Michel

1970 The order of things: An archaeology of the human sciences. London: Routledge.

1991 Discipline and Punish: The Birth of the Prison, trans. A. Sheridan. London: Penguin.

Fleming, Peter and Graham Sewell

2002 'Looking for the good soldier, Švejk: alternative modalities of resistance in the contemporary workplace’. Sociology 36/4: 857-873

Fleming, Peter and André Spicer

2003 'Working at a cynical distance: Implications for Power, subjectivity and resistance’. Organization 10/1: 157-179.

Fligstein, Neil.

1990 The transformation of corporate control. Cambridge, MA: Harvard University Press.

Fligstein, Neil

1996 'Markets as politics: A political-cultural approach to market institutions'. American Sociological Review 61/4: 656-673.

Ganesh, Shiv, Heather Zoller and George Cheney

2005 'Transforming resistance, broadening our boundaries: Critical organizational communication meets globalization from below'. Communication Monographs 72/2: 169-191.

Goodwin, Jeff, James M. Jasper, and Francesca Polletta, editors. 2001 Passionate politics. Chicago: University of Chicago Press. 
Gouldner, Alvin

1954 Wildcate strike: A study of worker-management relations. London: HarperTorchbooks.

Gramsci, Antonio

1971 Selection from prison notebooks. London: Lawrence \& Wishart.

Grant, David, Cynthia Hardy, Cliff Oswick and Linda Putnam, editors.

2004 The Sage handbook of organizational discourse. London: Sage.

Green, Anna

1992 'Spelling, go-slows, gliding away and theft: informal control over on the New Zealand waterfront, 1915-1951’. Labour History 63: 100-114.

Haines, Herbert $\mathrm{H}$.

1988 Black radicals and the civil rights mainstream, 1954-1970. Knoxville, TN: University of Tennessee Press.

Hancock, Philip and Melissa Tyler, editors

Forthcoming. The management of everyday life. London: Palgrave.

Haworth, Nigel and Stephen Hughes

2003 'International political economy and industrial relations'. British Journal of Industrial Relations 41/4: 665-82.

Hegel, G. W. F.

1821/2002 Phenomenology of spirit. New York: Oxford University Press.

Hensmans, Manuel.

2003 'Social movement organizations: A metaphor for strategic actors in institutional fields’. Organization Studies 24/3: 355-381.

Hobbes, Thomas

1651/1985 The Leviathan. London: Penguin.

Hyman, Richard

1973 Strikes. London: Fontana.

Jaffee, David, Jack Kloppenberger and Mario Monroy

2004 'Bringing the moral change home: Fairtrade within the North and within the South’. Rural Sociology 69/2: 169-196.

Jermier, John, David Knights and Walter Nord (eds.)

1994 Resistance and power in organizations. London: Routledge.

Jones, Campbell and André Spicer

2005 'The sublime object of entrepreneurship'. Organization 12/2: 223-46.

Kelly, John 
1998 Rethinking industrial relations: Mobilization, collectivism and longwaves. London: Routledge.

Knights, David and Darren MacCabe

2000 'Ain't misbehavin'? Opportunities for resistance under new forms of 'quality' management'. Sociology 34/3: 421-436.

2003 'Governing through teamwork: Reconstituting subjectivity in a call centre'. Journal of Management Studies 40/7: 1587-1619.

Knights, David and Hugh Willmott

1989 'Power and subjectivity at work: from degradation to subjugation in social relations'. Sociology 23/4: 535-58.

1990 (eds.) Labour process theory. London: Macmillan.

Laclau, Ernesto and Chantal Mouffe

1985 Hegemony and socialist strategy. London: Verso

2001 'Preface to the Second Edition' in Hegemony and socialist strategy, $2^{\text {nd }}$ Ed.

London: Verso.

Levy, David

2007 'Political contestation in global production networks'. Academy of Management Review, Forthcoming.

Levy, David L. and Daniel Egan

2003 'A neo-Gramscian approach to corporate political strategy: Conflict and accommodation in the climate change negotiations'. Journal of Management Studies 40/4: 803-830.

Levy, David and Maureen Scully

2007 'The institutional entrepreneur as modern prince: The strategic face of power in contested fields'. Organization Studies, Forthcoming.

Lounsbury, Michael

2001 'Institutional sources of practice varation: Staffing colleges and college recycling programmes’. Administrative Science Quarterly 46: 29-46.

Lounsbury, Michael, Marc Ventresca and Paul Hirsch

2003 'Social movements, field frames, and field frames: A cultural political perspective on the emergence of the US recycling industry'. Socio-economic Review 1: 71-104.

Luce, Stephanie

2005 'Lessons from living-wage campaigns'. Work and Occupations 32/4: 423-440.

Mars, Gerald

1982 Cheats at work: An anthropology of workplace crime. London: Counterpoint.

Marx, Karl

1976 Capital: A critique of political economy, Volume 1, trans. B. Fowkes. London: Penguin. 
McAdam, Douglas

1996 "Conceptual origins, current problems, future directions," in Comparative perspectives on social movements: Political opportunities, mobilizing structures, and cultural framings. D. McAdam, J.D. McCarthy and M.N. Zald (eds). Cambridge: Cambridge University Press.

McAdam, Douglas, John D. McCarthy, Mayer N. Zald, eds.

1996 Comparative perspectives on social movements: Political opportunities, mobilizing structures, and cultural framings. Cambridge: Cambridge University Press.

McCarthy, John D. and Mayer N. Zald

1987 'Resource mobilization and social movements: A partial theory', in Social movements in an organizational society: Collected essays. M.N. Zald and J.D. McCarthy (eds). New Brunswick, NJ: Transaction Books.

Melucci, Alberto

1989 Nomads of the present. London: Radius.

1996 Challenging codes: Collective action in the information age. Cambridge: Cambridge University Press.

Michels, Robert

1962 Political parties: A sociological study of the oligarchical tendencies of modern democracy, trans. Eden and Cedar Paul. New York: The Free Press.

Munck, Ronaldo

2000 Globalisation and labour: The new great transformation. London: Zed.

Newton, Tim

1998 'Theorising subjectivity in organizations: The failure of Foucauldian studies?'. Organization Studies 19/3: 415 - 457.

Newton, Tim

1999 'Power, subjectivity and British industrial and organizational sociology: The relevance of the work of Norbert Elias’. Sociology 33/2: 411-440.

Notes from Nowhere, editors

2003 We are everywhere: The irresistible rise of global anti-capitalism. London: Verso.

Ogbor, John O

2001 'Critical theory and the hegemony of corporate culture'. Journal of Organizational Change Management 14/6: 590-608.

Parker, Martin

2002 Against management: Organization in the age of managerialism. Cambridge: Polity.

Piven, Frances Fox and Richard Cloward

1979 Poor people's movements: Why they succeed, how they fail. New York: Vintage.

Perry, Nick 
1998 'Indecent exposures: Theorizing whistleblowing'. Organization Studies 19/2: 235257.

Plows, Alex

2006 'Blackwood roads protest 2004: An emerging (re)cycle of UK eco-action?'. Environmental Politics 15/3: 462-472.

Poggi, Gianfranco

2001 Forms of power. Cambridge: Polity.

Pollitt, Christopher

1993 Managerialism and the public service: The anglo-american experience. Cambridge, MA: Basil Blackwell.

Rao, Hayagreeva

1998 'Caveat emptor: The construction of nonprofit consumer watchdog organizations'. American Journal of Sociology 103/4: 912-61.

Rao, Hayagreeva, Calvin Morrill and Mayer Zald 2001 'Power plays: How social movements and collective action create new organizational forms’. Research in Organizational Behavior 22: 237-281.

Rao, Hayagreeva, Phillipe Monin and Rodolphe Durand

2003 'Institutional change in Toque Ville: Nouvelle cuisine as an identity movement in French gastronomy’. American Journal of Sociology 108/4: 795-843.

Reed, Michael

1997 'In praise of duality and dualism: Rethinking agency and structure in organizational analysis’. Organization Studies 18/1: 21-42.

Rich, Philip

1992 'The organizational taxonomy: Definition and design'. Academy of Management Review 17/4: 758-781.

Rodrigues, Suzanna and David Collinson

1995 'Having fun? Humour as resistance in Brazil'. Organization Studies 16/5: 739768.

Roy, Donald

1958 'Banana Time: Job satisfaction and informal interaction'. Human Organization 18/1: 158-161.

Scully, Maureen and Amy Segal

2000 'Passion with an umbrella: Grassroots activism in the workplace' in Research in the Sociology of Organizations, 19. M. Lounsbury and M. J. Ventresca (eds). Oxford: JAI Press.

Scott, Alan

1990 Ideology and the new social movements. London: Routledge. 
Scott, James C.

1990 Domination and the arts of resistance: Hidden transcript. New Haven, Conn: Yale University Press

Sewell, Graham and Barry Wilkinson

1992 'Someone to watch over me: Surveillance, discipline and the just-in-time labour process’. Sociology 26/2: 271-289.

Shenhav, Yehouda

1999 Manufacturing rationality: The engineering foundations of the managerial revolution. Oxford: Oxford University Press.

Spicer, André and Peter Fleming

Forthcoming 'Intervening in the inevitable: Globalization and resistance in the public sector’, Organization.

Tarrow, Sidney

1994 Power in movement: Social movements, collective action and politics. Cambridge: Cambridge University Press.

Taylor, Phil and Peter Bain

2003 'Subterranean worksick blues': Humour as subversion in two call centres'. Organization Studies 24/9: 1487-1509.

Thomas, Robyn and Annette Davies

2005 'Theorizing the micro-politics of resistance: New public management and managerial identities in the UK public services'. Organization Studies 26/5: 683-706.

Thomas, Robyn, Albert Mills and Jean Helms Mills

2004 Identity politics at work: Resisting gender, gendering resistance. London: Routledge.

Thompson, E. P.

1967 The making of the english working class. London: Penguin.

Thompson, Paul

1990 'Crawling from the wreckage,' in Labour process theory. D. Knights and H.

Willmott (eds). London: MacMillan.

Thompson, Paul and Stephen Ackroyd

1995 'All quiet on the workplace front? A critique of recent trends in British Industrial Sociology’. Sociology 29/4: 615-633.

Thompson, Paul and Chris Smith

2001 'Follow the redbrick road: Reflections on pathways in and out of the labor process debate’. International Studies on Management and Organization 30/4: 40-67.

Thornton, Patricia

2004 Markets from culture: Institutional logics and organizational decisions in highereducation publishing. Stanford, CA: Stanford University Press. 


\section{Thrift, Nigel}

2002 'Think and act like revolutionaries: Episodes from the global triumph of management discourse’. Critical Inquiry 44/3: 19-26.

Touraine, Alain

1981 The voice and the eye: An analysis of social movements. Cambridge: Cambridge University Press.

Tsoukas, Haridimos

1999 'David and Goliath in the risk society: Making sense of the conflict between Shell and Greenpeace in the North Sea’. Organization 6: 499-528.

Wallerstein, Michael and Bruce Western

2000 'Unions in decline? What has changed and why'. Annual Review of Political

Science 3: 355-377.

Willmott, Hugh

2005 'Theorizing contemporary control: Some post-structural responses to some critical realist questions’. Organization 12/5: 747-780.

Zald, Mayer N.

2005 'The strange career of an idea and its resurrection: Social movements in organizations’. Journal of Management Inquiry 14/2: 157-166.

Zald, Mayer N. and John D. McCarthy

1987 Social movements in an organizational society: Collected essays. New Brunswick, NJ: Transaction Books.

Zald, Mayer N. and Michael A. Berger

1978 'Social movements in organizations: Coup d'etat, insurgency, and mass movements’. American Journal of Sociology 83: 823-861. 
Figure 1: Two dimensions of resistance

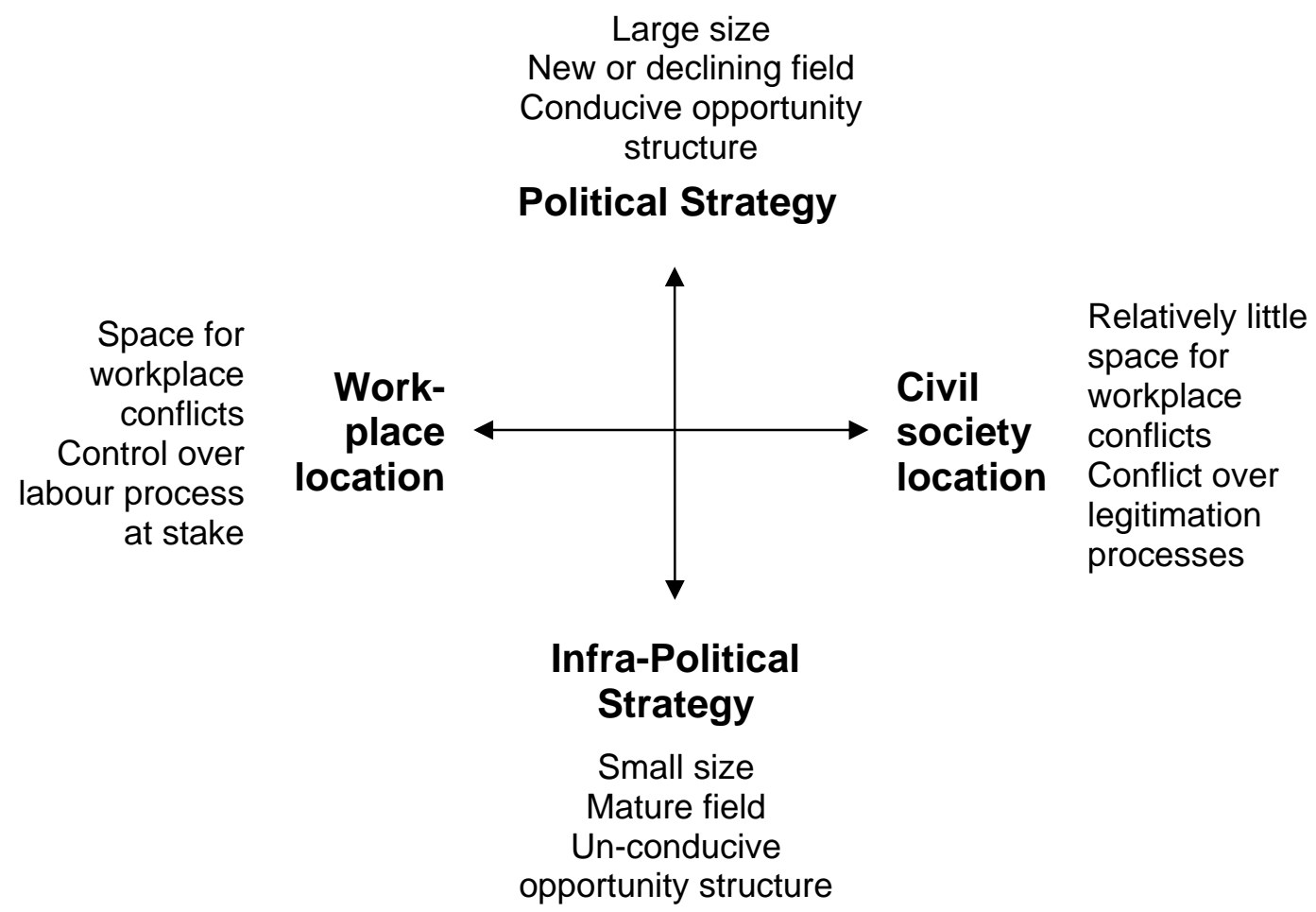

Figure 2: A model of resistance

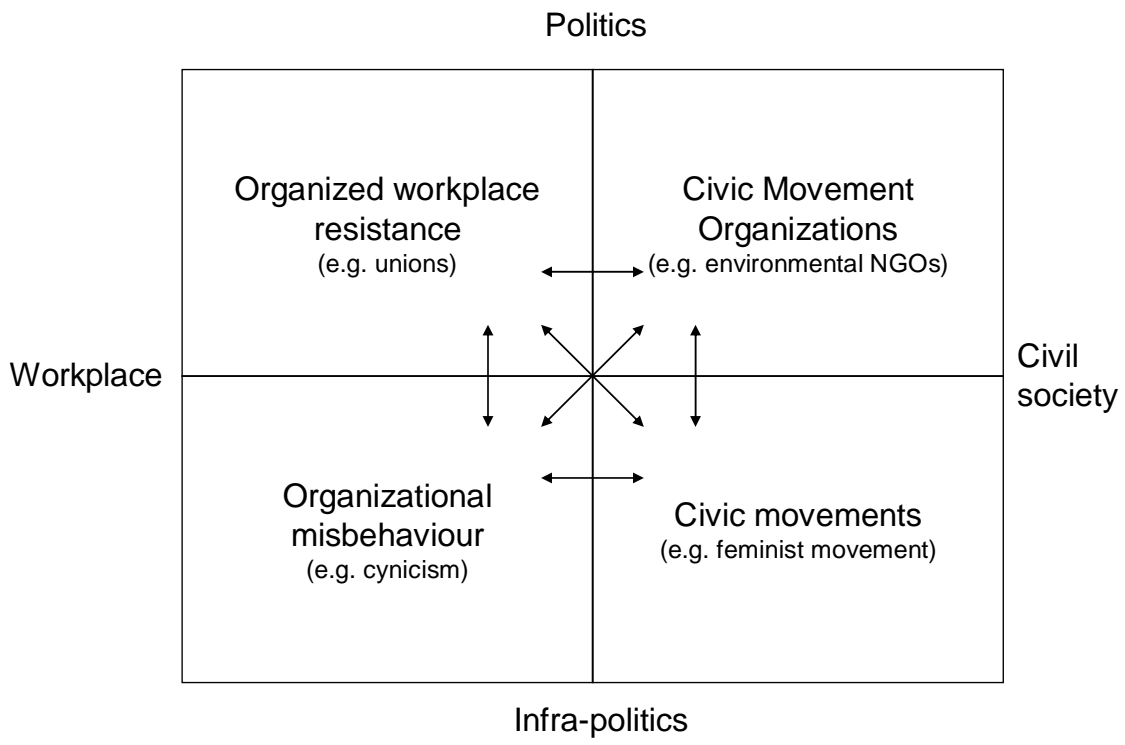

